Article

\title{
New Tillage System with Additional Renovation of Soil Properties in Tramlines
}

\author{
Vidas Damanauskas * and Danutė Jablonskytè-Raščè
}

check for updates

Citation: Damanauskas, V.; Jablonskytè-Raščè, D. New Tillage System with Additional Renovation of Soil Properties in Tramlines. Appl. Sci. 2021, 11, 2795. https://doi.org/ 10.3390/app11062795

Received: 28 February 2021

Accepted: 18 March 2021

Published: 21 March 2021

Publisher's Note: MDPI stays neutral with regard to jurisdictional claims in published maps and institutional affiliations.

Copyright: (c) 2021 by the authors. Licensee MDPI, Basel, Switzerland. This article is an open access article distributed under the terms and conditions of the Creative Commons Attribution (CC BY) license (https:// creativecommons.org/licenses/by/ $4.0 /)$.
Lithuanian Research Centre for Agriculture and Forestry, Joniškėlis Experimental Station, Karpių str. 1, LT-39301 Joniškèlis, Lithuania; jablonskyte-rasce@lammc.lt

* Correspondence: vidas.damanauskas@lammc.lt; Tel.: +370-451-38224

\begin{abstract}
Fertilizing and spraying techniques are repeatedly driven in tramlines for crop care with products whose demand increases for higher yields. The soil in tramlines is so compacted by heavy crop care machinery what leads breakdown to lifelessness. Such damaged state of the soil continues all season and leads to dejected soil productivity. The aim of this study is to find an optimal process of soil renovation in tramlines on loam and clay loam soil and to determine the required fuel consumption. The soil renovation was investigated by specially made Tiller on the dependence of tine shape types (narrow and winged) and working speed 1.6, 2.2 and $3.6 \mathrm{~m} \cdot \mathrm{s}^{-1}$ in loam and clay loam soil. The beneficial relationships of soil aggregate fraction ratio, which varied from 0.54 to 4.08 and fuel consumption, which varied from 1.04 to $1.82 \mathrm{~L} \cdot \mathrm{km}^{-1}$ independence on tine shape and soil type was established. Based on research results, the sufficient soil loosening to suitable proportion of soil aggregates fraction ratio on loam soil was accomplished at working speed $3.6 \mathrm{~m} \cdot \mathrm{s}^{-1}$ with winged tine type and fuel consumption was $1.04 \mathrm{~L} \cdot \mathrm{km}^{-1}$. The suitable soil aggregate fraction ratio on clay loam was achieved at working speed $3.6 \mathrm{~m} \cdot \mathrm{s}^{-1}$ with narrow tine shape type and fuel consumption was $1.31 \mathrm{~L} \cdot \mathrm{km}^{-1}$. The volume of loosed soil in tramlines was particularly influenced by variation of tines shapes but was not influenced by the working speed majorly. The aligning of soil surface was influenced by the working speed majorly and particularly by variation of tines shapes.
\end{abstract}

Keywords: tillage system; soil renovation; surface align; fuel consumption

\section{Introduction}

The farmlands size has tendency to increase, machinery designed more productive, at the same time more massive, thus increasing the negative soil compaction [1]. As the price of machinery rises, higher yields are also needed, it leads to intensiveness crop care. The tramlines for crop care are formed by seeding machines, into this line's seeds are not sown, the fertilization and spraying techniques are repeatedly driven with products whose demand increases for higher yields. The repetitive driving of wheeled machines during growing season are compressed the soil so much that it becomes destroyed completely, overloaded wheels formed the sinks. The soil compaction is the one of the main factors of soil degradation, food safety and productivity losses in agriculture system. During agricultural works with such machines the soil has been worsened not only by compaction of the weight, but also by inappropriate management of soil tillage in unfavorable moisture conditions in medium and low temperature regions like North-Western Europe [2]. The degree of soil damaging depends on several factors and their interaction. Soil compaction as soil damaging due to vehicular traffic in too wet conditions induces soil structure deterioration and soil deformation [3]. The degree of soil compaction during field traffic depends largely on the soil water content [4]. It changes soil properties: increasing bulk density, soil penetration resistance and decreasing porosity, rainwater infiltration and aeration [5]. A lot of studies covering a range of different soil types have reported significant compaction effects on structural conditions to deep subsoil layers [6-9]. According to findings, the wheel load and moisture has a dominating compaction effect in deep and 
topsoil layers [10-14]. The effect of repeated tractor wheeling on stress/strain and physical properties is higher than one-time wheeling [15]. The studies of Lipiec et al. (1992) has quantified the effect of repeated short-term stress application (e.g., passage of several wheels after each other) and found that the vertical deformation of the plough layer soil was linearly related to the logarithm of the number of wheel passes [16]. The same compaction by numerous wheels of tractor with attached spraying or fertilizing equipment wheels arises in tramlines. The regular crop maintenance with fertilizers and sprayers machinery is required according to it crop grow stage, but to the soil moisture conditions, which may be very vulnerable and not suitable, is not considered. In the opinion of this research' authors, the compaction of subsoil influenced the water infiltration mainly, the compaction of topsoil is more actual of its exclusive use of crop growth, yield and all agriculture systems. Subsoil all over loosening could be carried out periodically every few years, its more commonly applied at the ends of the fields, where agriculture technique turns around. The passage of crop care wheeled machines in tramlines create various objective problems, such as: soil compression and hardening [17,18]; soil erosion and degradation [19]; crop yield losses [20]. The physical properties of soil in tramlines are particularly damaged due to transport mode of tractor tires air pressure, ballast, narrow tires of spreader and axle overload [21,22]. This long-term soil compaction in tramlines through growth season increases negative effectthere are no plants and their roots-what interacts with the extinction of soil biota and loses nutrients $[23,24]$. The tramlines as hard soil barriers impede tillage operations-regime of implements is uneven; traction force is unstable and increases too high overload especially at "no-till" agriculture system. Moreover, the clumps of such dense soil are formed during the following soil tillage operations, they are carried to all field where the crop will grow next year, and when they dry part of them is impossible to smash and properly prepare seedbed. The tramlines are formed during crop sowing from one or another field's side and these tramlines may be formed in another place at next year's seeding or for different crop type rotation - they will not be needed at all. When this happens, the crop is sown in this have-been place of tramlines where the soil is damaged, crops do not have conditions for growing and developing. The tillage systems must manage to build healthier soils with improved soil structure to manage water resources better and reduce soil erosion. The properly done post-harvest shallow tillage contributes to soil improvement and save fuel consumption [25]. Šařec and Šařec (2015) studied the regime of various cultivators and offers recommendations for loosening of wheel tracks and headlands prior to stubble cultivation, and to loosen the whole field prior to sowing [26].

The paper gives one advice, if the tramlines cannot be avoided-to restore the soil properties in their have-been place. This is a separate and a short tillage operation, which can be done at the busy post-harvest season. The preserving of soil properties is the headache of crop farmers, they spend hours for reducing tillage, applying the nutrients, increasing organic matter, and decreasing the negative impact to environmental. Overall optimization of tillage systems can reduce fuel expenditure, at the same time environmental pollution [27-29]. Implements for cultivating and restore such compressed soil in tramlines relatively not much. The aim of this study is to find the optimal working regimes by specially made Wheel Track Tiller for required soil renovation in tramlines on loam and clay loam soil and to determine dependencies of fuel consumption.

\section{Materials and Methods}

\subsection{The Engineering of Investigation}

The evaluation and comparisons of data were made on different ploughing soils: clay loam and loam on winter wheat stubble witch height was $8 \pm 2 \mathrm{~cm}$. Research was done in the northern part of Central Lithuania's lowland on loam soil $\left(55^{\circ} 58^{\prime} 21.59^{\prime \prime} \mathrm{N}, 24^{\circ} 13^{\prime} 8.6^{\prime \prime} \mathrm{E}\right)$ and clay loam soil $\left(56^{\circ} 2^{\prime} 6.71^{\prime \prime} \mathrm{N}, 24^{\circ} 11^{\prime} 46.43^{\prime \prime} \mathrm{E}\right)$ at the Joniškèlis Experimental Station of Lithuanian Research Centre for Agriculture and Forestry. The tests were accomplished by the special Wheel Track Tiller (WTT) which was designed in company Laumetris Ltd. (Keleriškiai village, Kèdainiai district, Lithuania) WTT consist of sections for each track: 
tine, couple of discs with opposite disc angle and a roller. The sections have a possibility to change the tines shape and to control their width of position from 1.5 to $2.5 \mathrm{~m}$. Two types of ordinary tines shapes were used-narrow and winged (Figure 1). The tines run on the center of tramline, opposite discs returned the soil from sides and a roller kept tillage depth in partly smashing clumps. The chisel tine "BELOTA" of model 12466-V-AF assembly has been selected as its especially designed for cultivators that are used for work in the vineyards. It is designed to be assembled on $80 \times 80$ frame with chisel tines of a $30 \times 30$ or $35 \times 35$ profile, intended use for till soil to maximum of $30 \mathrm{~cm}$ deep. The tractor "Ford 8340 SLE" ( $82.3 \mathrm{~kW})$ was equipped by technique to evaluate fuel consumption. The tillage was performed at depth $24 \mathrm{~cm}$, the tractor's engine speed was fixed as field work at $1500 \pm 10 \mathrm{~s}^{-1}$ and working speed of aggregate $\left(1.6 ; 2.2\right.$ and $\left.3.6 \pm 0.1 \mathrm{~m} \cdot \mathrm{s}^{-1}\right)$ was achieved by changing varied gears.

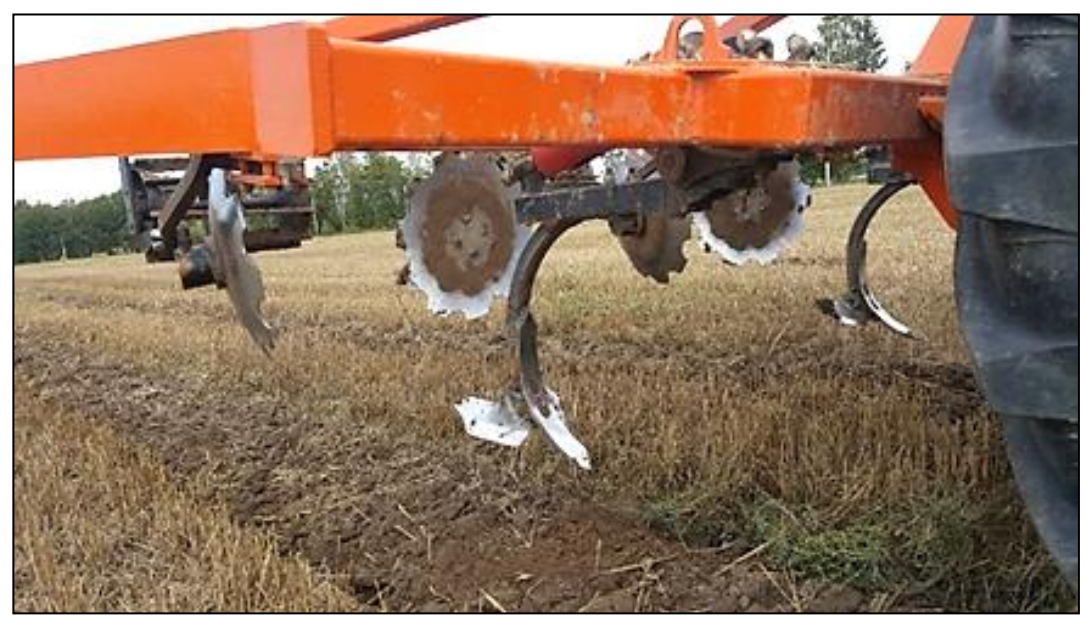

(a)

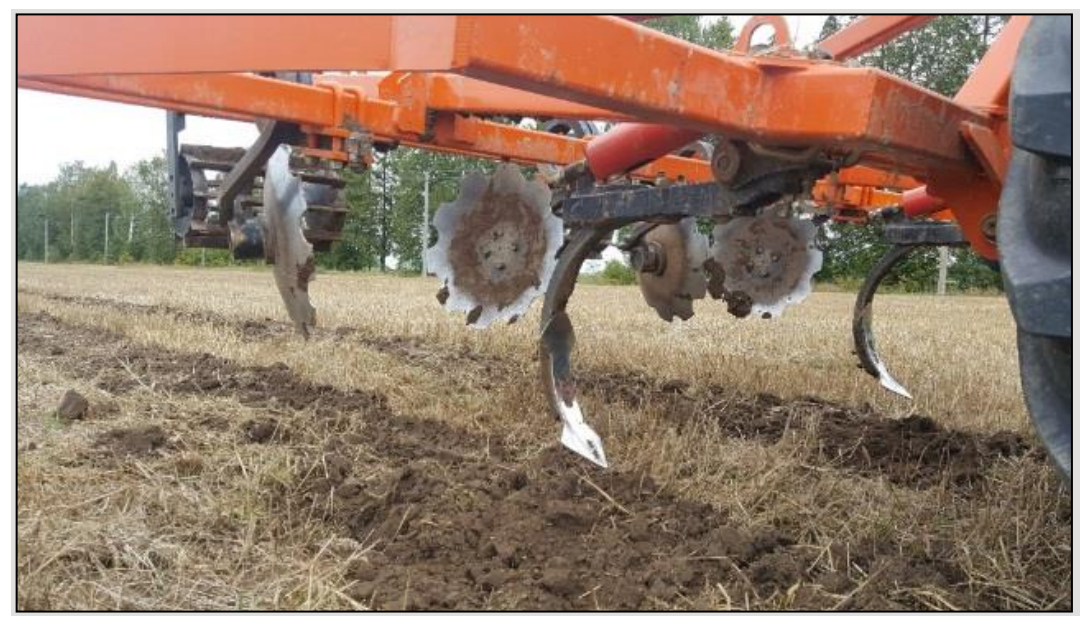

(b)

Figure 1. Winged tine shape (a) and narrow (double end) tine shape (b).

The renovation of tramlines soil physical state defined by soil structure and soil surface levelling must be accomplished with lowest fuel consumption required to achieve sufficiently correct renovation quality. The determination of initial soil conditions in tramlines was done by measurements of soil surface roughness, bulk density, and soil penetration resistance. After renovation of tramlines the estimating of soil surface and bottom geometry, soil aggregate proportion ratio (ks) and determination of fuel consumption (FC) by three replications by each aggregate regime mode was done. 


\subsection{The Assessment of Soil Conditions}

The soil characteristics of compacted tramlines was evaluated before the renovation experiment. The soil penetration resistance of the tramline middle and both sides were measured on loam and clay loam soil. The penetrometer Eijkelkamp was used with iron cone $1.0 \mathrm{~cm}^{2}$ and angle of $60^{\circ}$ and measurements of penetration were done. The soil profile was measured by ruler for estimation soil surface geometry of compacted tramlines. The soil bulk density and water content in tramlines and not compacted soil sample were determined by standard cylinder weight method. Differences of soil conditions are explained by the naturally different physical properties of investigative soil. The quality of soil renovation in tramlines were estimated by soil aggregates fraction proportion ratio and soil surface and loosed soil bottom geometry. Three soil aggregate fractions (fine, medium, and coarse) volume $\left(\mathrm{m}^{3}\right)$ were pre-sorted, and the ratio of soil aggregate size proportion was calculated. The distribution of aggregate size was determined by the standard sieve method by using sieves set and its fractions of tilled soil sample were calculated according to the methodology provided in literature [30,31]. Soil layer was taken in the descriptive places of treatment and were served with sieve set and divided into three aggregate fractions: fine $<10 \mathrm{~mm}$, medium $10-20 \mathrm{~mm}$, coarse $>20 \mathrm{~mm}$ [32]. The fine and medium aggregate fraction $\left(M_{\text {medium }}, M_{\text {fine }}\right)$ has good aeration, water infiltration and seed-soil contact, which makes best conditions for seeds germination and plant residues decomposition $[16,33]$. Coarse aggregates $\left(M_{\text {coarse }}\right)$ deposited to dry and hard clods that is hard to smash and even some of them-almost impossible. Such soil aggregate structure characteristic brings out low level of seed germination, poor soil contact with plant residues and respectively poor organic matter decomposition. The blocking of dry crust is more noticeable in the clay loam soil. The soil aggregates ratio estimated as ks and showed the significant differences between the treatments of tillage regime mode combinations. The soil aggregate ratio was calculated by the division of sum medium and fine soil aggregate fraction to the coarse soil aggregates fractions:

$$
k_{s}=\frac{M_{\text {fine }}+M_{\text {medium }}}{M_{\text {coarse }}}
$$

\subsection{The Measurements of Fuel Consumption}

The measurements of hourly fuel consumption $\left(\mathrm{L} \cdot \mathrm{h}^{-1}\right)$, were done by added fuel consumption gauge, fuel filter, fuel cooler and air separator in the main fuel system of engine (Figure 2). Working speed of tractor was measured by original speed radar.

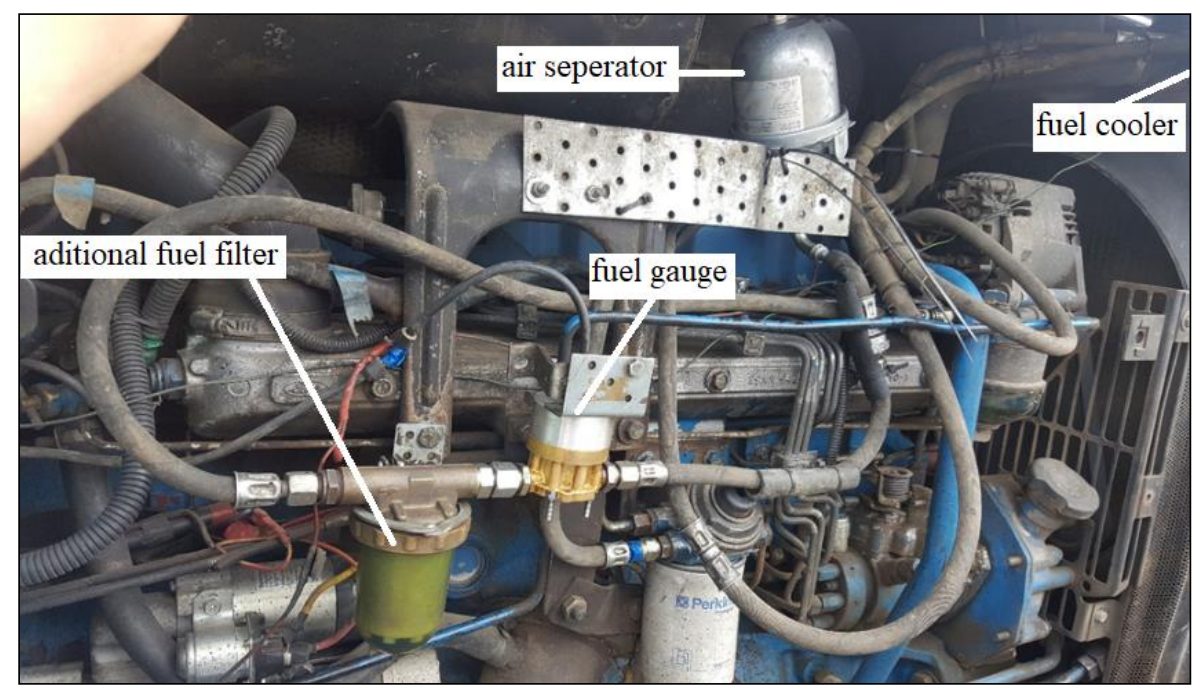

Figure 2. The additional technique to evaluate fuel consumption of tractor. 
The built-in speed radar, fuel consumption gauge and tractor's alternator were connected to the installed instrument system data recorder "SKRT-21 Lite" and the software "SKRT-MANAGER". Hourly fuel consumption was measured by fuel flow meter VZO4 OEM (Aquametro), which was fitted into the low-pressure fuel supply system of "Ford 8340" tractor engine. Additionally, fuel cooling radiator, filter and air separator were installed to ensure the work fluency of fuel flow meter. Signals were recorded by the data recorder. Fuel consumption was calculated only for the technological process of renovation tramlines. The treatments were performed only on the tramlines, so fuel consumption was converted to track length. Fuel consumption per kilometer $F C_{k m}$ was calculated according to the following equation:

$$
F C_{k n}=\frac{F C_{h}}{3.6 \cdot \tau \cdot v}, \mathrm{~L} \cdot \mathrm{km}^{-1}
$$

where: $F C_{h}$ is hourly fuel consumption $\left(\mathrm{L} \cdot \mathrm{h}^{-1}\right), \tau$-utilization ratio of working time, and $v$ is the field speed $\left(\mathrm{m} \cdot \mathrm{s}^{-1}\right)$.

Fuel consumption for the turns of the unit was not included. Deviation of data was based on the characteristic of the devices. The statistical analysis of results showed significant differences between the aggregate regime mode combinations of hourly fuel consumption and fuel consumption per kilometer of tramline. Data were processed using the XLSTAT software (Addinsoft, Paris, France), using one-way analysis of variance ANOVA and Tukey's (HSD) test at confidence level $p=0.05$. Multivariate principal component analysis was performed. The data scattering of soil state measurements is presented.

\section{Results and Discussion}

\subsection{The Dependence of Bottom and Surface on tine Type and Working Speed}

After harvest, usually in "reduced-till" system, the shallow tillage is used, but working parts of implement do not reach the bottom of tramlines, cannot loosen soil, properly mix residues into the soil in these tramlines. The sinks of soil surface were estimated $6 \pm 0.5 \mathrm{~cm}$, the cross section of compressed soil area $280 \pm 15 \mathrm{~cm}^{2}$ (Figure 3). The tillage depth of opposite disc was selected $6 \div 8 \mathrm{~cm}$, only for soil surface aligning. The measurements of soil density, water content and soil penetration resistance (Figures 4 and 5) show that the psychical differences of compacted and not compacted soil were mostly in the ploughing soil layer from 0 to $25 \mathrm{~cm}$.

Both graphs indicate that loosening of deeper soil layer is not required strongly, in addition the undesirable subsoil layer would be raised by these shapes. This is the reason for eliminating topsoil density and the study of tillage options and determination of fuel consumption. However, we are looking for tillage regime of WTT aggregate to restore the soil properties exactly in this layer up to $25 \mathrm{~cm}$.

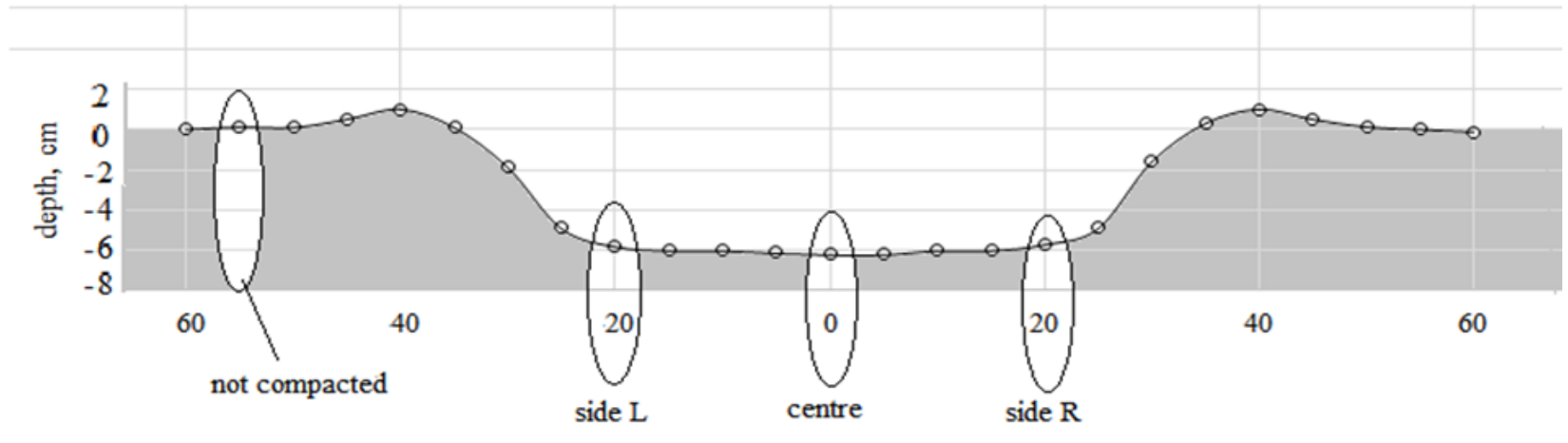

Figure 3. Principal scheme of measurements in tramline profile. 


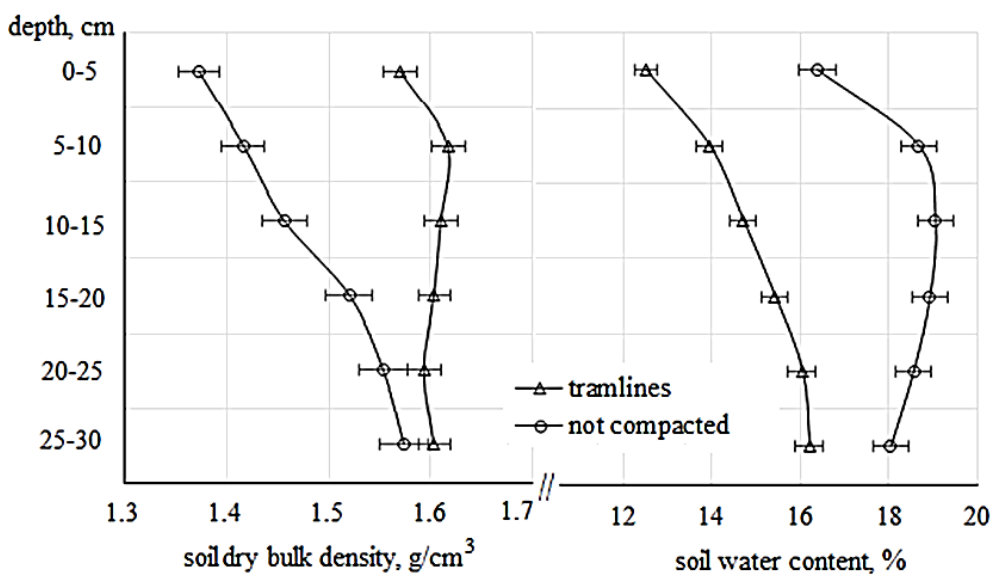

(a)

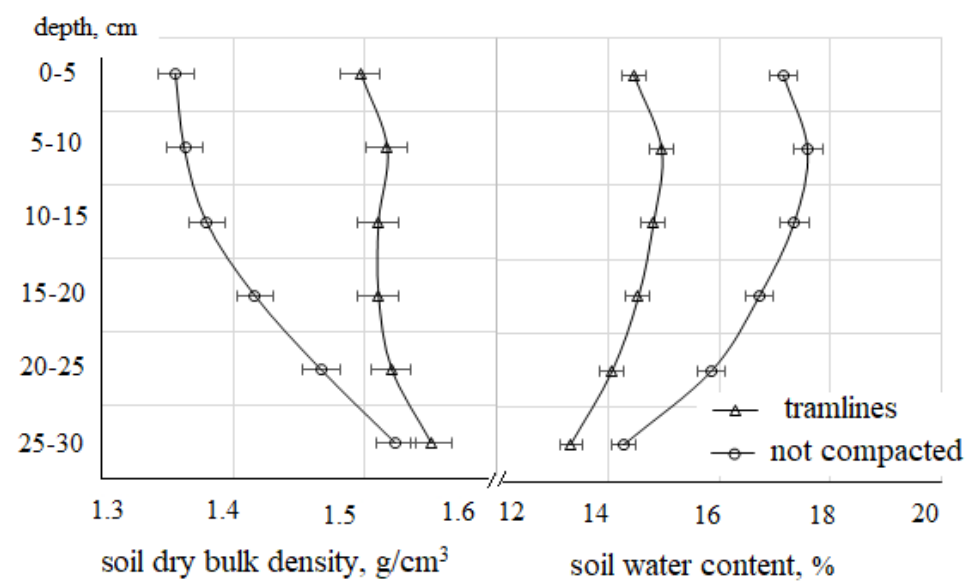

(b)

Figure 4. Soil dry bulk density and water content on clay loam (a) and loam soil (b).

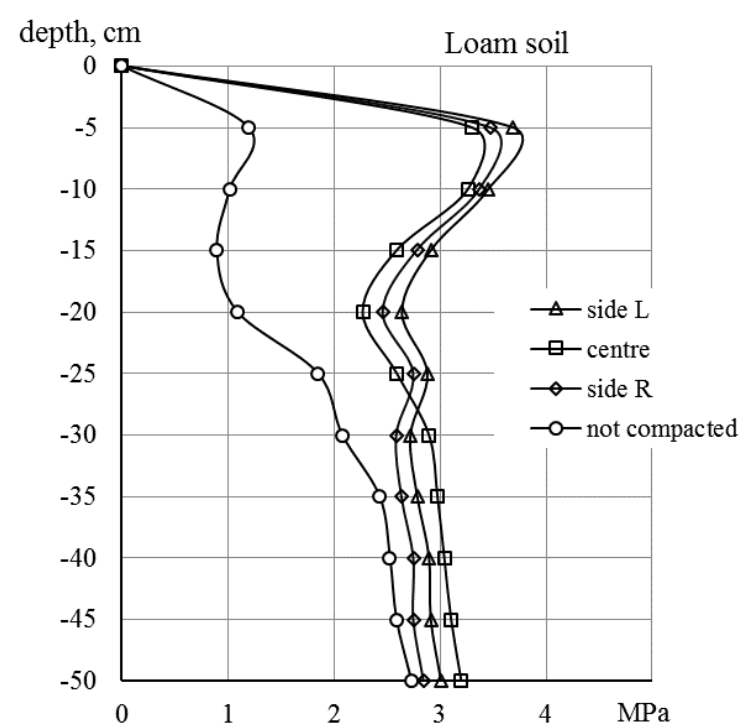

(a)

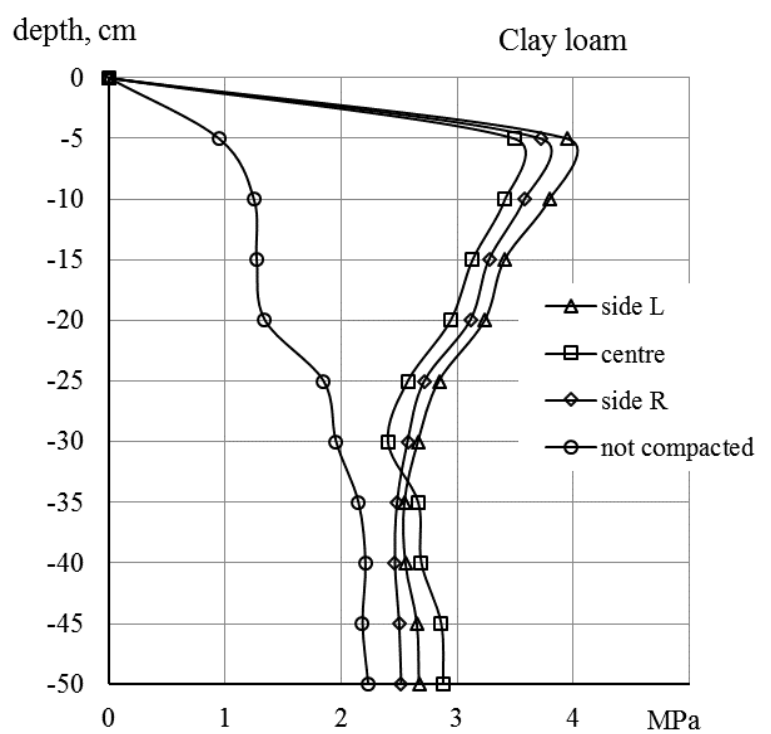

(b)

Figure 5. Soil penetration resistance on loam soil (a) and clay loam soil (b). 
Various scenarios of tramlines renovation and its quality level were obtained by changing the types of tines shapes and working speed. It was found that additional settings can provide positive soil structure and its fraction aggregate size proportions in loam and clay loam soil. The WTT performs three functions: tines crust the soil, disc blades return soil to wheeling's and roller crumble clods, and that contributes to the aligning of soil surface. The WTT also mixed wheat stubble, what lying on tramlines surface after the harvest, slightly added to the tramline place and will restore the soil organic matter shortage over the year. The bottom line of loosed soil in have-been tramline was influenced by a variety of tines shapes but was not influenced significantly by working speed (Figure 6). The bottom line of restored tramlines in loam and clay loam soil were similar, loosened soil area varied in the range of error and not discussed separately. Winged tines have loosened the bigger cross area of soil and it was $860 \pm 8 \mathrm{~cm}^{2}$, while narrow tines did not cover all the width of tramline and have loosened only $660 \pm 8 \mathrm{~cm}^{2}$.

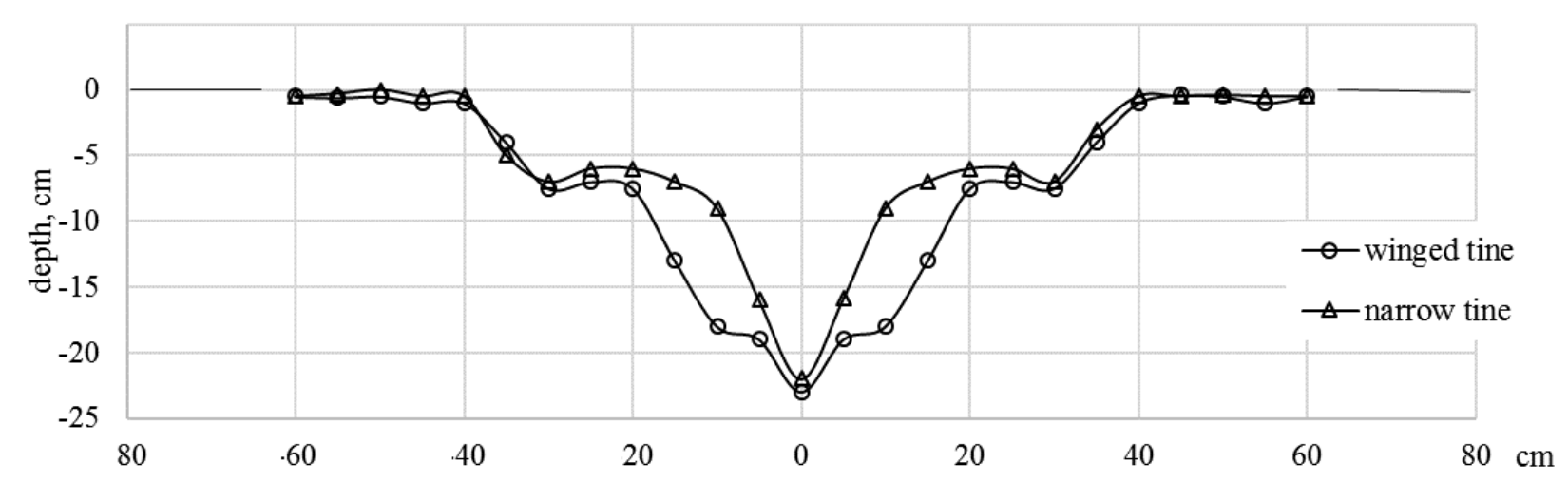

Figure 6. The cross section of bottom of loosed soil in tramlines in dependense ot tine shape.

The surface of tramlines was influenced majorly by working speed and particularly by variation of tines shapes. Soil surface was formed mainly by opposite discs, that at highest speed $\left(3.6 \mathrm{~m} \cdot \mathrm{s}^{-1}\right)$ supplementary upthrow and formed higher soil pile (Figure 7). Moreover, better lifting, crusting of soil layer and more intense straw mixing with both tines' shapes were observed at this faster speed.

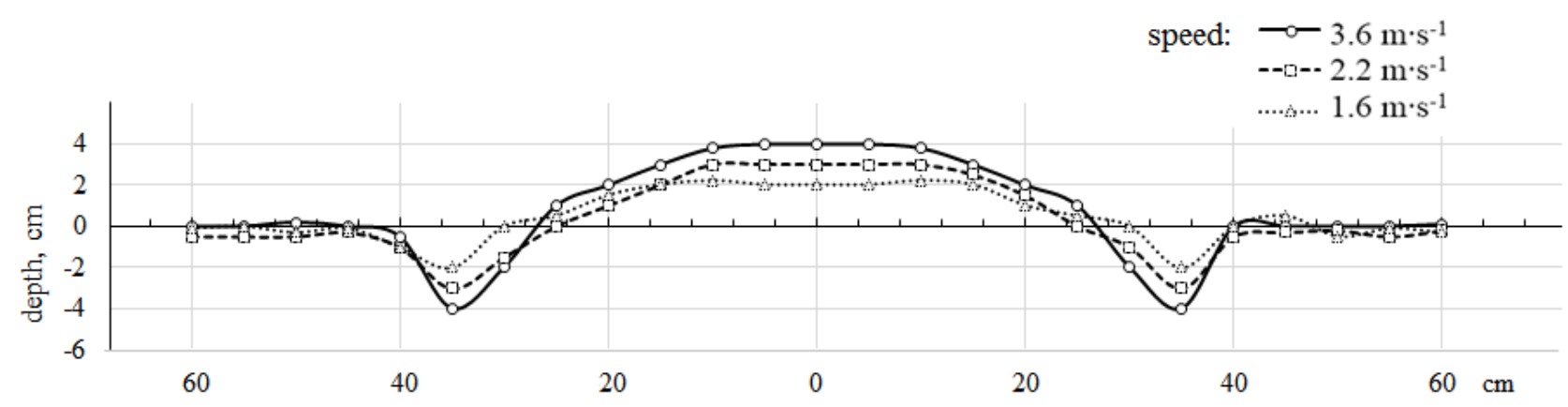

Figure 7. The cross section of loosed soil surface of tramline.

\subsection{Dependence of Soil Aggregates Fraction Ratio on Variation of Speed and Tine Types}

Pires et al. [34] proposed that soil structure represents one of the main soil physical attributes indicators of crop rooting zone. The porous system of renovated soil is directly linked to water retention, root development, gas diffusion and the conditions for all soil biota are related in forming soil structure [35]. The effects of the tillage operations on the soil system must be considered with improved soil structure and residue management, better rooting makes the crop more efficient into the soil profile. Results are showed that type of tines shapes and working speed influenced the soil aggregate fraction ratio (ks). The 
narrow shape moved soil in front of itself, rolled up and more intensive crashed compacted soil at increased speed mainly. The winged shape lifted soil, created disturbed area, and did not crush intensively compacted layer to fine soil aggregates fraction. A higher volume of coarse fraction was observed in clay loam to compare with loam soil. As expected, the area of disturbed soil was greater with winged shape type, this is considered as better option, similarly as [36]. The significant differences of soil structure aggregates fraction ratio are noticeable between treatments in variation tines shapes types and working speed regime. The aggregates fraction ratio ks increases from 0.63 to 1.34 with narrow shape when the working speed increased from 1.6 to $3.6 \mathrm{~m} \cdot \mathrm{s}^{-1}$ on clay loam soil, and on loam soil-from 1.12 to 4.08 (Figures 8 and 9). The loosening with winged tine shape, when the working speed increased from 1.6 to $3.6 \mathrm{~m} \cdot \mathrm{s}^{-1}$ on clay loam soil, aggregates fraction ratio ks increased from 0.54 to 1.18 , on loam soil-from 0.97 to 2.48 .

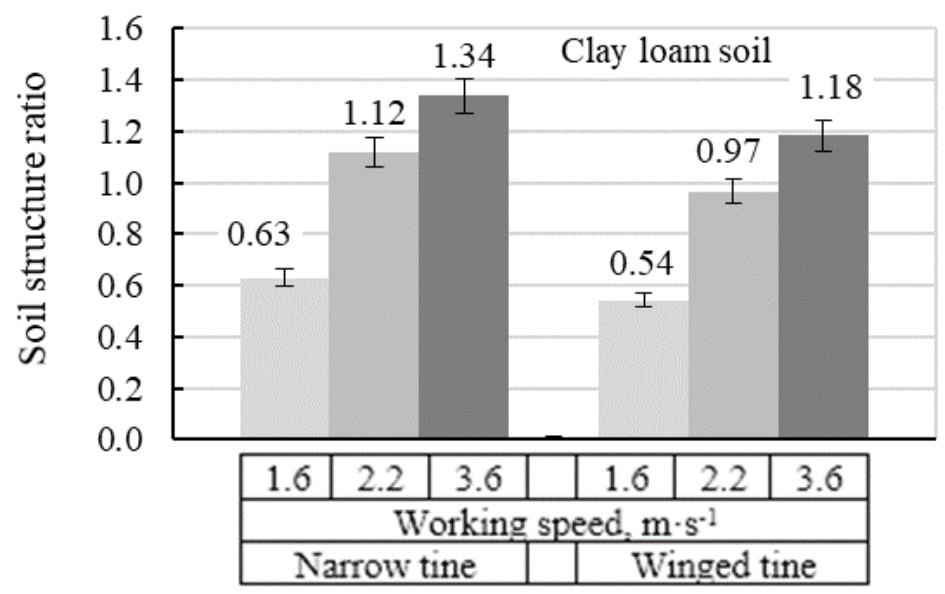

Figure 8. Dependence of soil structure fraction ratio on speed and tine types on clay loam.

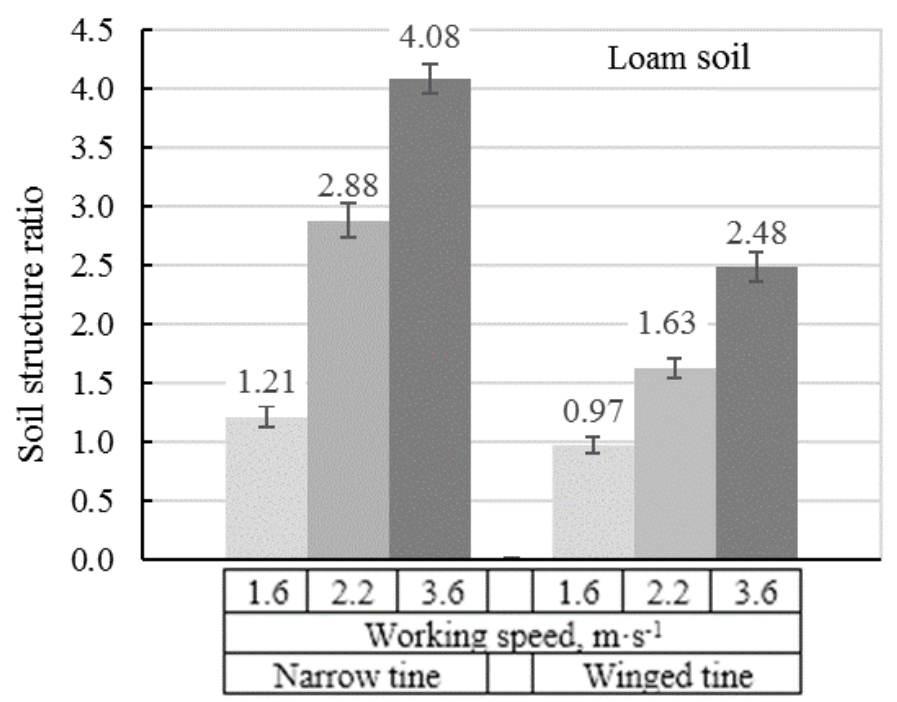

Figure 9. Dependence of soil structure fraction ratio on speed and tine types loam soil.

The soil aggregates ratio ks was insufficient with both tines types when working speed was minimal $\left(1.6 \mathrm{~m} \cdot \mathrm{s}^{-1}\right)$. The amount of large course soil aggregates was about twice greater than during the tillage test at high working speed $\left(3.6 \mathrm{~m} \cdot \mathrm{s}^{-1}\right)$. Results reveal that respectable value of soil structure aggregates ratio on clay loam was obtained by narrow tine shape, proceeding treatment at maximum speed, however, on loam soil-by winged tine, at average speed. According to results, it is stated, that the increasing of working speed has the effect on more qualitatively clay loam soil structure. It can be said that its need 
to increase working speed on clay loam soil, because the inertia force helps to granulate soil structure [35]. Therefore, in comparison results of soil structure ratio ks shows that it is necessary to use the different equipment's adjustment on different soils types-what especially relevant for tillage in the same field with different soil types. During the next operation tillage by moldboard plough, it was observed that soil structure was better and smaller clumps were formed in the fields with restored tramlines.

\subsection{Dependence of Fuel Consumption on Variety of Tine Types and Working Speed}

The hourly fuel consumption depends on the tractor draft force which required to pull an implement [25]. Draft force depends on adjustments of implementing and working speed as accessible tillage level, and it defined as tractor drawbar resistance [27]. Various tillage system scenarios for soil tramline's renovation quality level were obtained by changing the tine shape type and working speed. It was found that adjustments that request to obtain the desirable level of soil renovation influenced the hourly fuel consumption from 7.9 to $17 \mathrm{~L} \cdot \mathrm{h}^{-1}$ (Figures 10 and 11). The fuel consumption was higher on clay loam than on loam soil by using the same working adjustment, due to greater compression hardening of clay loam soil.

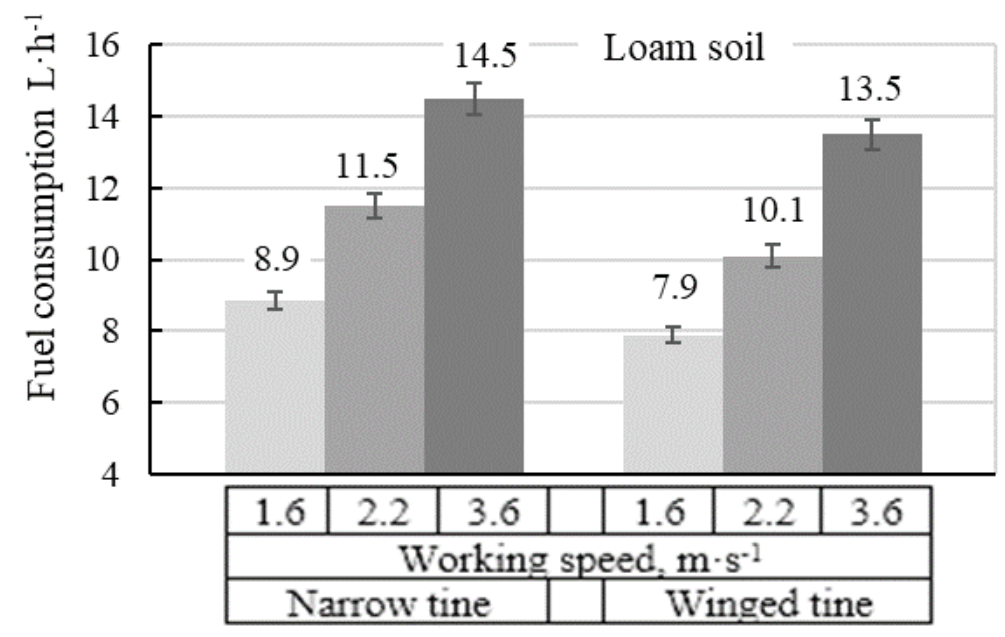

Figure 10. Dependence of hourly fuel consumption on speed and tine types on loam.

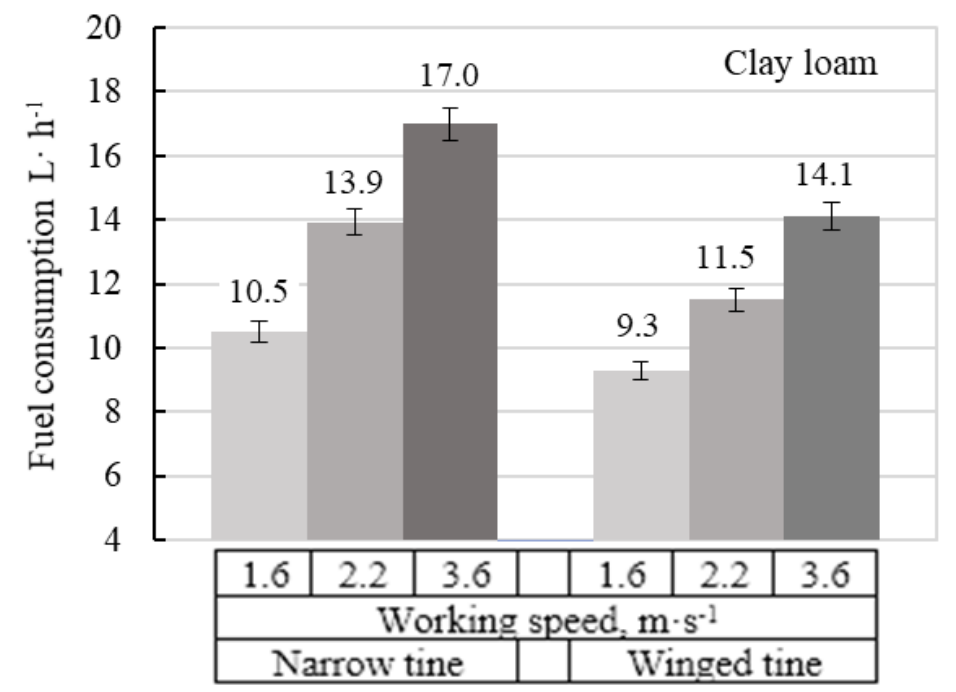

Figure 11. Dependence of hourly fuel consumption on speed and tine types on clay loam soil. 
The results of performed experiment showed, that the hourly fuel consumption depends more on working speed, than on tine types, which explains that movement of tractor itself requires higher fuel content and more energy is needed to overcome inertial soil forces. It was found that hourly fuel consumption has direct relation with tillage resistance level and soil type: on clay loam it was $1.5-2.5 \mathrm{~L} \cdot \mathrm{h}^{-1}$ higher than on loam soil. When the speed was increased from 1.6 to $3.6 \mathrm{~m} \cdot \mathrm{s}^{-1}$, the hourly fuel consumption in loam soil increased from 7.9 to $14.5 \mathrm{~L} \cdot \mathrm{h}^{-1}$, and on clay loam soil-from 9.3 to $17.0 \mathrm{~L} \cdot \mathrm{h}^{-1}$ independent of type shape. Hourly fuel consumption was increased from 14.1 to $17.0 \mathrm{~L} \cdot \mathrm{h}^{-1}$ when winged shape was changed to narrow tines shape type on clay loam at maximum working speed $\left(3.6 \mathrm{~m} \cdot \mathrm{s}^{-1}\right)$ and from 9.3 to $10.5 \mathrm{~L} \cdot \mathrm{h}^{-1}$ at minimum speed $\left(1.6 \mathrm{~m} \cdot \mathrm{s}^{-1}\right)$. When the shape was settled from winged to narrow, the hourly fuel consumption increased $1.0-1.3 \mathrm{~L} \cdot \mathrm{h}^{-1}$ on loam soil, and $1.2-2.9 \mathrm{~L} \cdot \mathrm{h}^{-1}$ on clay loam.

The efficiency of tractor fuel use is better reflected in fuel consumption of soil tillage per hectare, but in this case, it was calculated for the tramline's tillage length $\left(\mathrm{L}^{\circ} \cdot \mathrm{km}^{-1}\right)$. Fuel consumption per hectare is possible to count only approximately because width track lines are different, it depends on the spraying width of crop care machines, usually the fields are irregular shapes; for example, if the spraying width is $20 \mathrm{~m}$, then 10 ha field has $5 \mathrm{~km}$ of tramlines, plus tramlines at the ends of fields. Fuel consumption per $1 \mathrm{~km}$ length of tramline tillage depends on working speed and type shape, it increases when winged shape was changed to narrow type but decreases with increasing the working speed.

The results illustrate the possibility of restoring the tramlines on loam soil with fuel consumption from 1.04 to $1.54 \mathrm{~L} \cdot \mathrm{km}^{-1}$, on clay loam soil-from 1.15 to $1.82 \mathrm{~L} \cdot \mathrm{km}^{-1}$, on dependence of selected tillage mode (Figures 12 and 13). The shape type's changing from winged to narrow increased the fuel consumption per $1 \mathrm{~km}$ length from 0.08 to $0.17 \mathrm{~L} \cdot \mathrm{km}^{-1}$ on loam soil and on clay loam soil-from 0.16 to $0.21 \mathrm{~L} \cdot \mathrm{km}^{-1}$. When the tillage speed was increased from 1.6 to $3.6 \mathrm{~m} \cdot \mathrm{s}^{-1}$ by winged shape the fuel consumption decreased regarding $0.4-0.5 \mathrm{~L} \cdot \mathrm{km}^{-1}$, and nearly $0.3-0.4 \mathrm{~L} \cdot \mathrm{km}^{-1}$ by narrow shape on both loam and clay loam soils.

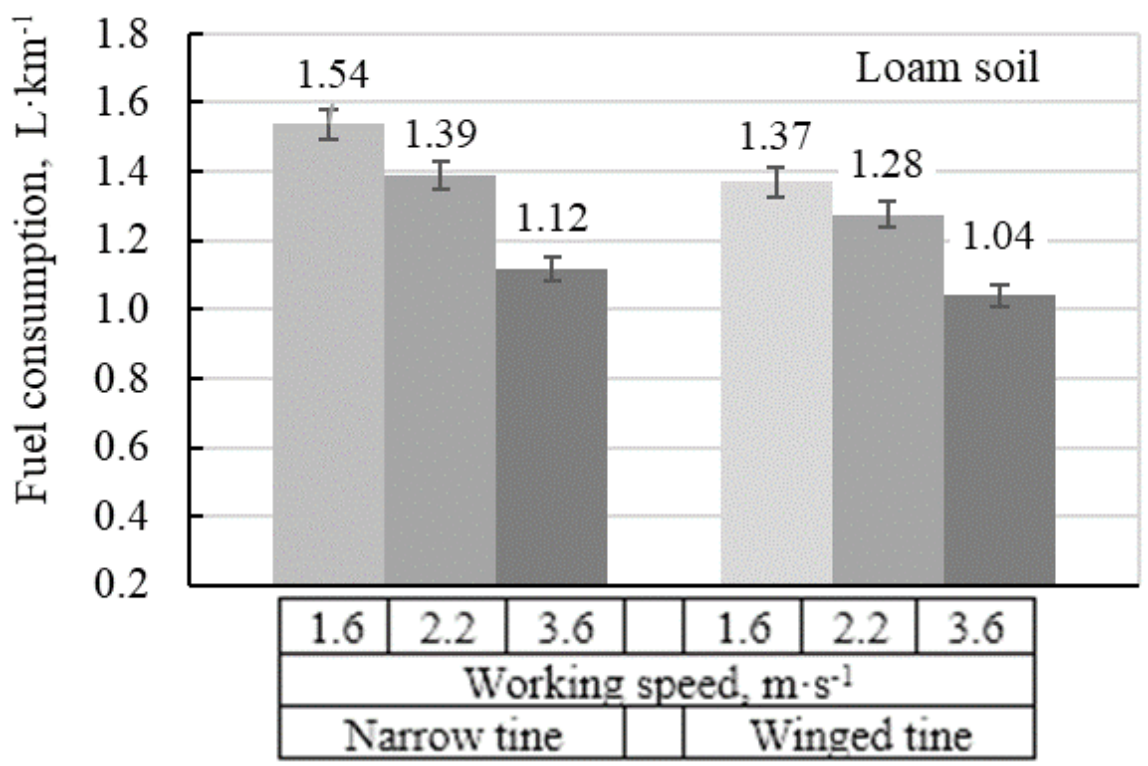

Figure 12. Dependence of fuel consumption on speed and tine types on loam soil. 


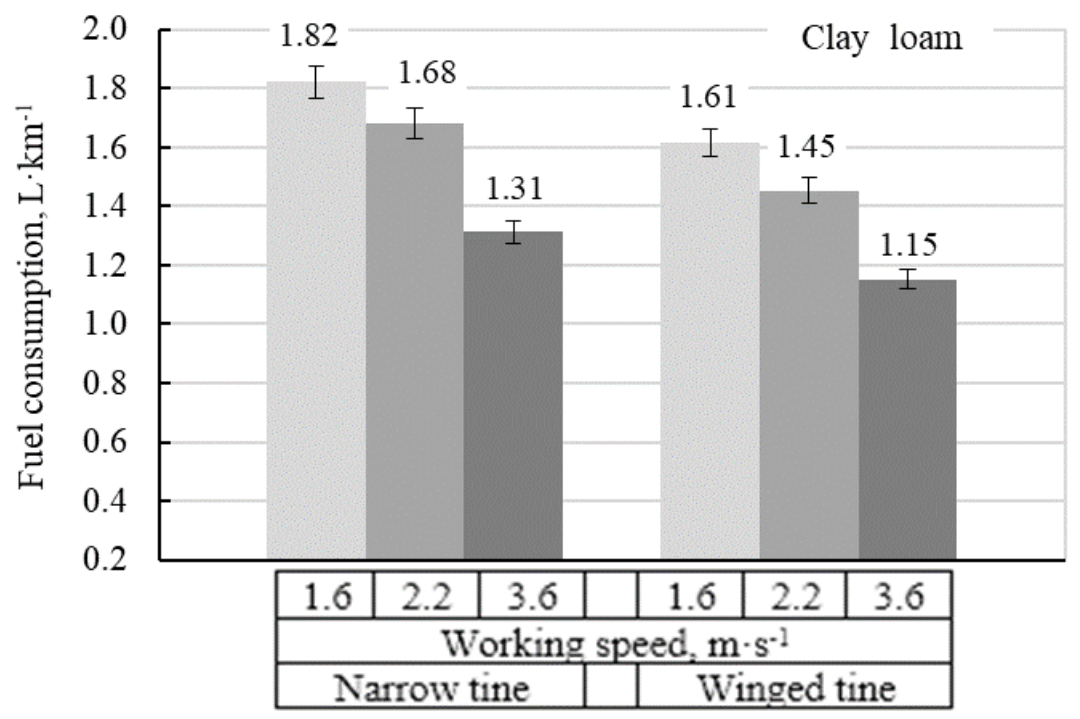

Figure 13. Dependence of fuel consumption on speed and tine types clay loam soil.

\section{Conclusions}

The results of adjusting this specific practice study provide helpful indications for the any tillage system and appropriate choices of tractor and implement configurations for soil renovation, optimizing energy requirement on different soils, thereby reducing tillage costs when compacted soil in tramlines was restored before the main tillage.

1. The aligning of soil surface weakly influenced by shape types and mostly influenced by working speed. Powerful soil loosening created more fluffy content, opposite discs developed greater frowning force and continued to throw the soil sample. At faster working speed the height of soil sample was $2.0 \pm 0.3 \mathrm{~cm}$ higher than at slowest working speed.

2. Based on results, the highest soil structure fraction ratio on clay loam and on loam was reached with narrow shape type at faster working speed. The appropriate and desirable soil structure ratio on clay loam soil was obtained with narrow shape type at highest speed, on loam soil was obtained with winged shape type at middle speed.

3. The hourly fuel consumption for soil renovation varied depending on selected tillage regime mode and soil type. To restore the $1 \mathrm{~km}$ length of tramline on loam soil required fuel consumption varied depending on selected tillage regime. The minimum fuel consumption was $1.04 \mathrm{~L} \cdot \mathrm{km}^{-1}$ on loam soil and $1.15 \mathrm{~L} \cdot \mathrm{km}^{-1}$ on clay loam with winged tine shape at highest working speed.

Author Contributions: All authors have performed study in equal parts and agreed to publish the manuscript. All authors have read and agreed to the published version of the manuscript.

Funding: This research received no external funding.

Institutional Review Board Statement: Not applicable.

Informed Consent Statement: Not applicable.

Data Availability Statement: The data supporting the findings of this study are available within the article.

Acknowledgments: This research supported by the research program "Productivity and sustainability of agricultural and forest soils" implemented by Lithuanian Research Centre for Agriculture and Forestry.

Conflicts of Interest: The authors declare no conflict of interest. 


\section{References}

1. Keller, T.; Sandina, M.; Colombia, T.; Horn, R.; Ore, D. Historical increase in agricultural machinery weights enhanced soil stress levels and adversely affected soil functioning. Soil Tillage Res. 2019, 194, 104293. [CrossRef]

2. Hamza, M.A.; Anderson, W.K. Soil compaction in cropping systems: A review of the nature, causes and possible solutions. Soil Tillage Res. 2005, 82, 121-145. [CrossRef]

3. Håkansson, I.; Voorhees, W.B.; Riley, H. Vehicle and wheel factors influencing soil compaction and crop response in different traffic regimes. Soil Tillage Res. 1988, 11, 239-282. [CrossRef]

4. Trautner, A.; Arvidsson, J. Subsoil compaction caused by machinery traffic on a Swedish Eutric Cambisol at different soil water contents. Soil Tillage Res. 2003, 73, 107-118. [CrossRef]

5. Lipiec, J.; Hatano, R. Quantification of compaction effects on soil physical properties and crop growth. Geoderma 2003, 116, 107-136. [CrossRef]

6. Horn, R.; Fleige, H. Risk assessment of subsoil compaction for arable soils in Northwest Germany at farm scale. Soil Tillage Res. 2009, 102, 201-208. [CrossRef]

7. Jakobsen, B.F.; Dexter, A.R. Prediction of soil compaction under pneumatic tires. J. Terramechanics 1989, 26, 107-119. [CrossRef]

8. Håkansson, I.; Voorhees, W.B.; Elonen, P.; Raghavan, G.S.V.; Lowery, B.; van Wijk, A.L.M.; Rasmussen, K.; Riley, H. Effect of high axle-load traffic on subsoil compaction and crop yield in humid regions with annual freezing. Soil Tillage Res. 1987, 10, 259-268. [CrossRef]

9. Alakukku, L. Persistence of soil compaction due to high axle load traffic. II. Long term effects on the properties of fine-textured and organic soils. Soil Tillage Res. 1996, 37, 223-238. [CrossRef]

10. Arvidsson, J. Subsoil compaction caused by heavy sugar beet harvesters in southern Sweden: I. Soil physical properties and crop yield in six field experiments. Soil Tillage Res. 2001, 60, 67-78. [CrossRef]

11. Arvidsson, J.; Keller, T. Soil stress as affected by wheel load and tire inflation pressure. Soil Tillage Res. 2007, 96, 284-291. [CrossRef]

12. Horn, R.; Fleige, H. A method for assessing the impact of load on mechanical stability and on physical properties of soils. Soil Tillage Res. 2003, 73, 89-99. [CrossRef]

13. Lamandé, M.; Schjønning, P. Transmission of vertical stress in a real soil profile. Part III: Effect of soil water content. Soil Tillage Res. 2011, 114, 78-85. [CrossRef]

14. Moncada, M.P.; Munkholm, L.J.; Schjønning, P. Wheel load, repeated wheeling, and traction effects on subsoil compaction in northern Europe. Soil Tillage Res. 2019, 186, 300-309. [CrossRef]

15. Horn, R.; Way, T.; Rostek, J. Effect of repeated tractor wheeling on stress/strain properties and consequences on physical properties in structured arable soils. Soil Tillage Res. 2003, 73, 101-106. [CrossRef]

16. Lipiec, J.; Szustak, S.; Tarkiewicz, S. Soil compaction: Responses of soil physical properties and crop growth. Zeszyty Problemowe Postepów Nauk Rolniczych 1992, 398, 113-117.

17. Pytka, J. Effects of repeated rolling of agricultural tractors on soil stress and deformation state in sand and loess. Soil Tillage Res. 2005, 82, 77-88. [CrossRef]

18. Håkansson, I.; Reeder, R.C. Subsoil compaction by vehicles with high axle load extent, persistence, and crop response. Soil Tillage Res. 1994, 29, 277-304. [CrossRef]

19. Saggau, P.; Michael Kuhwald, M.; Duttmann, R. Integrating soil compaction impacts of tramlines into soil erosion modelling: A field-scale approach. Soil Syst. 2019, 3, 51-55. [CrossRef]

20. Arvidsson, J.; Håkansson, I. A model for estimating crop yield losses caused by soil compaction. Soil Tillage Res. 1991, 20 , 319-332. [CrossRef]

21. Håkansson, I.; Medvedev, V.W. Protection of soils from mechanical overloading by establishing limits for stresses caused by heavy vehicles. Soil Tillage Res. 1995, 35, 85-97. [CrossRef]

22. Ansorge, D.; Godwin, R.J. The effect of tyres and a rubber track at high axle loads on soil compaction, part 1: Single axle-studies. Biosyst. Eng. 2007, 98, 115-126. [CrossRef]

23. Colombia, T.; Keller, T. Developing strategies to recover crop productivity after soil compaction-A plant eco-physiological perspective. Soil Tillage Res. 2019, 191, 156-161. [CrossRef]

24. Chan, K.Y.; Oates, A.; Stan, A.D.; Hayes, R.C.; Dear, B.S.; Peoples, M.B. Agronomic consequences of tractor wheel compaction on a clay soil. Soil Tillage Res. 2006, 89, 13-21. [CrossRef]

25. Damanauskas, V.; Velykis, A.; Satkus, A. Efficiency of disc harrow adjustment for stubble tillage quality and fuel consumption. Soil Tillage Res. 2019, 194, 104311. [CrossRef]

26. Šařec, P.; Šařec, O. Employment characteristics of tine cultivators at deeper soil loosening. Res. Agric. Eng. 2015, 61, 80-86. [CrossRef]

27. Čiplienè, A.; Gurevičius, P.; Janulevičius, A.; Damanauskas, V. Experimental validation of tire inflation pressure model to reduce fuel consumption during soil tillage. Biosyst. Eng. 2019, 186, 45-59. [CrossRef]

28. Janulevičius, A.; Damanauskas, V. How to select air pressures in the tires of MFWD (mechanical front-wheel drive) tractor to minimize fuel consumption for the case of reasonable wheel slip. Energy 2015, 90, 691-700. [CrossRef]

29. Lovarelli, D.; Bacenetti, J.; Fiala, M. Effect of local conditions and machinery characteristics on the environmental impacts of primary soil tillage. J. Clean. Prod. 2017, 140, 479-491. [CrossRef] 
30. Slawiñski, C.; Witkowska-Walczak, B.; Lipiec, J.; Nosalewicz, A. Effect of aggregate size on water movement in soils. Int. Agrophys. 2011, 25, 53-58.

31. Velykis, A.; Satkus, A. The impact of tillage, Ca-amendment and cover crop on the physical state of a clay loam soil. Zemdirb. Agric. 2018, 105, 3-10. [CrossRef]

32. Mueller, L.; Shepherd, G.; Schindler, U.; Ball, B.C.; Munkholm, L.J.; Hennings, V.; Smolentseva, E.; Rukhovic, O.; Lukin, S.; Hui, C. Evaluation of soil structure in the framework of an overall soil quality rating. Soil Tillage Res. 2013, 127, 74-84. [CrossRef]

33. Nugis, E.; Velykis, A.; Satkus, A. Estimation of soil structure and physical state in the seedbed under different tillage and environmental conditions. Zemdirb. Agric. 2016, 103, 243-250. [CrossRef]

34. Pires, L.F.; Borges, J.A.R.; Rosa, J.A.; Cooper, M.; Heck, R.J.; Passoni, S.; Roque, W.L. Soil structure changes induced by tillage systems. Soil Tillage Res. 2017, 165, 66-79. [CrossRef]

35. Dexter, A.R. Soil physical quality Part I. Theory, effects of soil texture, density, and organic matter, and effects on root growth Geoderma 2004, 120, 201-214. [CrossRef]

36. Nunes, M.R.; Denardin, J.E.; Pauletto, E.A.; Faganello, A.; Pinto, L.F.S. Effect of soil chiseling on soil structure and root growth for a clayey soil under no-tillage. Geoderma 2015, 259-260, 149-155. [CrossRef] 